\title{
Eclogites and garnet pyroxenites from Kimberley, W. Kaapvaal craton, South Africa: severe metasomatism of basaltic cumulates
}

\author{
Q. Shu $^{1 *}$, G.P. Brey ${ }^{2}$, D.G. Pearson ${ }^{1}$ \\ ${ }^{1}$ Dept. of Earth and Atmospheric Sciences, University of Alberta, Edmonton, Canada T6G 2E3. \\ ${ }^{2}$ Institut für Geowissenschaften, Goethe-Universität, Frankfurt, Germany \\ *qshu1@ualberta.ca
}

\section{Introduction}

In contrast to the great abundance of peridotite xenoliths erupted by the Kimberley pipes, eclogites from this mantle section are very scarce, being only reported by Jacob et al. (2009). The reworking of the Boshof Road dump allowed the collection of 16 new eclogite and garnet pyroxenites with dimensions of 3-6 cm from the coarse concentrate of the diamond recovery plant established at the former DeBeers mine. Depending on composition, these xenoliths consist of orangey to brown garnets and pale to dark green clinopyroxenes. Half of them have $2-4 \%$ phlogopite and two are opxbearing.
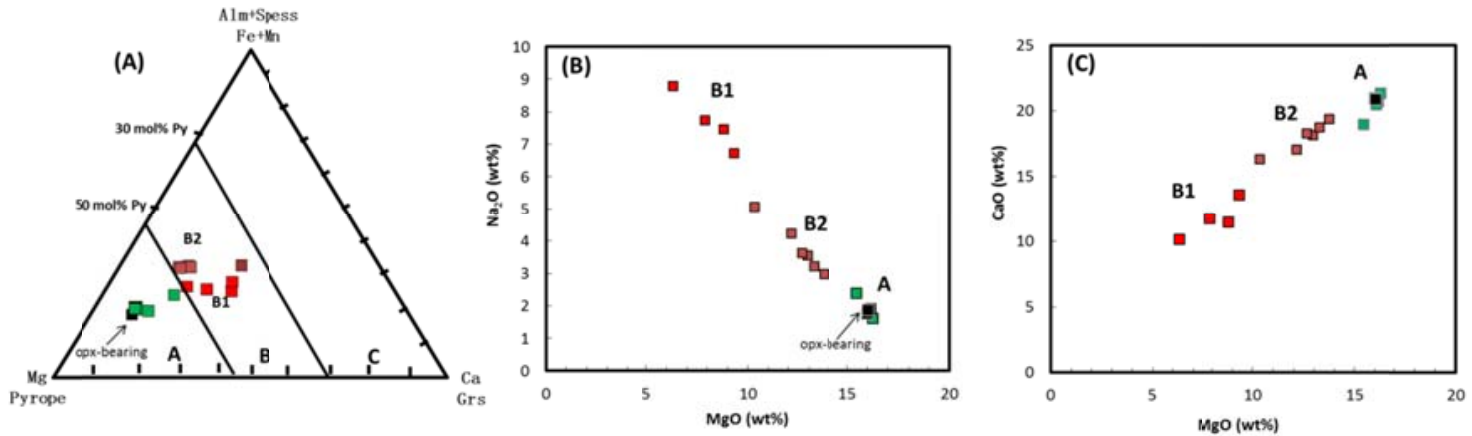

Fig.1 Major element compositions of garnets and clinopyroxenes. The square symbols with various colours present samples from this study divided into 3 groups: A, B1and B2. (A) Trilateral garnet composition diagram after Coleman et al., 1965; (B) $\mathrm{MgO}(\%)$ vs. $\mathrm{Na}_{2} \mathrm{O}$ (\%) variation of clinopyroxenes; (C) $\mathrm{MgO}(\%)$ vs. $\mathrm{CaO}$ (\%) variation in clinopyroxenes
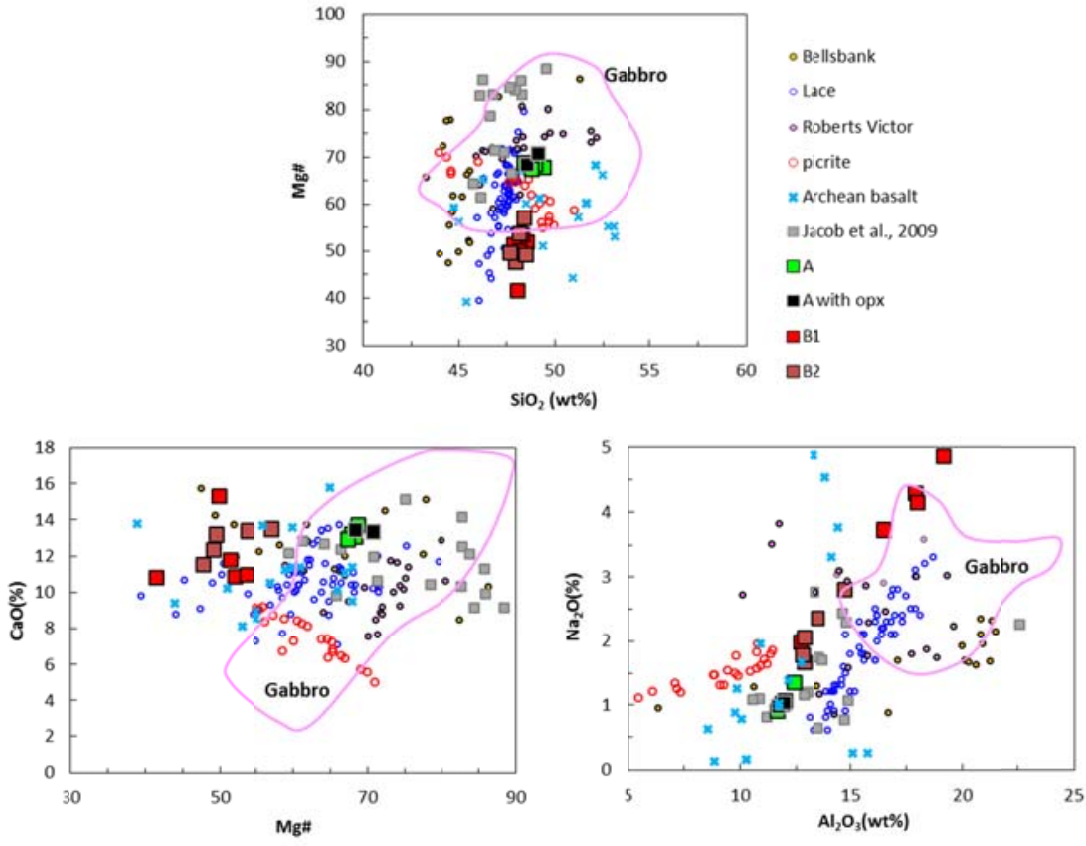
Fig.2 (A) Calculated major element bulk-rock compositions of eclogites from Kimberley mine (this study) and data from Jacob et al., 2009 for eclogites from Kimberley and other locations on the Kaapvaal craton shown in Mg\# vs. $\mathrm{SiO}_{2}$ (A), Mg\# vs. $\mathrm{CaO}$ (B) and $\mathrm{Al}_{2} \mathrm{O}_{3}$ vs. $\mathrm{Na}_{2} \mathrm{O}$ (C) diagrams. Also shown are fields for Archean basalts (Polat et al., 2003), Hawaiian picritic basalts (Norman and Garcia 1999) and modlern gabbroic rocks (SE Indian Ridge, Hart et al., 1999; Bach et al., 2001).

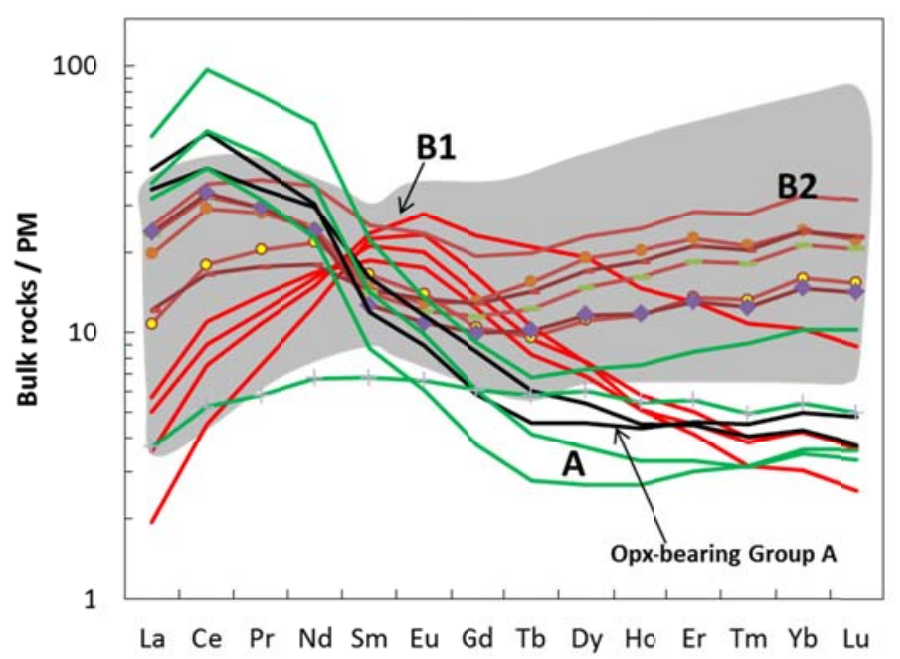

Fig.3 Spidergram for recalculated bulk rock compositions using mineral modal abundances of garnet: clinopyroxene $=45 \%: 55 \%$ normalized to values for primitive mantle (McDonough, Sun 1995). The bulk-rock compositional range of Kimberley eclogites from a previous study are shown for comparison (grey area, Jacob et al., 2009).

$\mathrm{F}$

\section{Results and preliminary conclusion}

Kimberley eclogite garnet compositions fall in the A and B fields of the classification scheme of Coleman et al. (1965; Fig.1). They are further divided into groups A, B1 and B2 according to the major and trace element characteristics of the garnets and their coexisting clinopyroxenes. The suite of xenoliths in this study shows considerably wider compositional range than the suite reported by Jacob et al. (2009). Group A xenoliths contain pyrope-rich garnet (mostly around $\mathrm{Py}_{70} \mathrm{Alm}_{10} \mathrm{Grs}_{20}$ ) associated with jadeite-poor clinopyroxenes that qualifies them as garnet pyroxenites. Two have coexisting orthopyroxene. Their reconstructed bulk-rock major element compositions resemble modern-day gabbroic rocks (Fig.2). The HREE abundances of the calculated bulk rocks are 3 to 8 times that of the primitive mantle (PM) while the lighter REE steeply increase up to 100x PM for Ce (Fig.3). This group of Kimberley xenoliths may have an origin as high-pressure, high-temperature clinopyroxene cumulates in the lower oceanic crust (e.g. Barth et al., 2001; Schmickler et al., 2004) or within the shallow mantle (Bodinier and Godard, 2005). They were heavily metasomatized in incompatible elements after metamorphism. Group B2 xenoliths have garnets ranging from $\mathrm{Py}_{48} \mathrm{Alm}_{34} \mathrm{Grs}_{18}$ to $\mathrm{Py}_{57} \mathrm{Alm}_{25} \mathrm{Grs}_{18}$ and omphacites with 3-5 \% $\mathrm{Na}_{2} \mathrm{O}, 10-14 \% \mathrm{MgO}$ and $10-14 \% \mathrm{CaO}$ (Fig.1). Their reconstructed bulk-rock major element compositions are comparable to Archean basalts (Fig.2). The MREE and HREE mantle-normalised profiles of the calculated bulk rocks are positively sloped with abundances between 12 to 20 times PM, indicating some degree of partial melting in the garnet stability filed while the strongly increased LREE indicate subsequent metasomatism. Group B1 xenoliths are more like eclogites sensu stricto. They possess more Ca-rich garnets ranging from $\mathrm{Py}_{35} \mathrm{Alm}_{34} \mathrm{Grs}_{31}$ to $\mathrm{Py}_{52} \mathrm{Alm}_{28} \mathrm{Grs}_{20}$ associated with jadeite-rich clinopyroxenes with low Mg\#. The REE patterns of the calculated bulk rocks are unique for eclogites. They slope from a hump at $\sim 10$ to 20 x PM Eu down to 2x PM for La and 3x PM for Lu. They may have been plagioclase rich cumulates that were subsequently severely overprinted by metasomatism after subduction.

Temperatures of last equilibration before kimberlite eruption were determined with the $\mathrm{Fe}^{2+}$ Mg garnet-clinopyroxene exchange thermometer of Krogh et al. (1988) and extrapolated to a 40 
$\mathrm{mW} / \mathrm{m}^{2}$ conductive geothermal gradient. Interestingly, the three petrologic groups of eclogites mainly fall into three distinctive pressure-temperature ranges, suggesting that they occupy spatially distinct depths in the lithospheric mantle: Group A samples yield temperatures between 930 and $970^{\circ} \mathrm{C}$ and pressures between 3.9 to $4.1 \mathrm{GPa}$, Group B2 samples range from 1038 to $1110^{\circ} \mathrm{C}$ and 4.6 to $5.1 \mathrm{GPa}$ and group B1 eclogites have highest temperatures and pressures, from 1175 to $1236{ }^{\circ} \mathrm{C}$ and 5.6 to 6.2 $\mathrm{GPa}$, sitting at the base of the Kimberley lithospheric mantle. This range in equilibration temperatures and depths indicates a distribution of these lithologies throughout the lithospheric mantle, in contrast to the suggestion by Huang et al., (2012).

In summary, a new expanded eclogite suite from Kimberley shows a much wider bulk and mineral chemical compositional range compared to the initial study of Kimberley eclogites performed by of Jacob et al (2009). Metasomatism is a dominant feature in the eclogites from Kimberley, in keeping with the highly metasomatized nature of the garnet peridotites from Kimberley (REFERENCES, e.g., Simon et al., 2003). Despite of various levels of overprinting, especially on the highly incompatible trace elements, major elements and less incompatible to compatible trace elements still reflect, to a large extent, the protoliths of these rocks. The wide range of depths of derivation indicates a distribution of mafic lithologies through the Kimberley lithospheric mantle column. The distinctive trace element compositions among different eclogite/pyroxenite groups at Kimberley allow us to investigate the metasomatic profile in the cratonic mantle and to reconstruct the metasomatic history via radiometric systems - work currently in progress.

\section{References}

Bach W, Alt JC, Niu YL, Humphries SE, Erzinger JA, Dick HJB (2001) The geochemical consequences of late-stage low-grade alteration of lower ocean crust at the SW Indian Ridge: Results from ODP Hole 735B (Leg 176), Geochimica Et Cosmochimica Acta 65(19): 3267-3287.

Barth M, Rudnick RL, Horn I, McDonough WF, Spicuzza M, Valley JW, Haggerty SE (2001) Geochemistry of xenolithic eclogites from West Africa, part I: a link between low MgO eclogites and Archean crust formation, Geochimica Et Cosmochimica Acta 65: 1499 - 1527.

Bodinier, J-L Godard M (2005) Orogenic, ophiolitic, and abyssal peridotites. In: Carlson RW, Holland HD, Turekian KK (Eds.), Treatise on Geochemistry. The Mantle and Core, vol. 2. Elsevier, pp. 103-170.

Coleman RG, Lee DE, Beatty LB, Brannock WW (1965) Eclogites and eclogites; their differences and similarities, GeoI Soc. Ama. BulI 76: 483-508.

Hart SR, Blusztajn J, Dick H.J.B., Meyer P.S.and Muehlenbachs K, (1999) The fingerprint of seawater circulation in a 500-meter section of ocean crust gabbros, Geochimica et Cosmochimica Acta 63, 4059-4080.

Huang JX, Gréau Y, Griffin W L, O'Reilly YS, Pearson JN, (2012) Multi-stage origin of Roberts Victor eclogites: Progressive metasomatism and its isotopic effects, Lithos 142-143: 161-181.

Jacob DE, Viljoen KS, Grassineau NV (2009) Eclogite xenoliths from Kimberley, South Africa - a case study of mantle metasomatism in eclogites, Lithos 112(S): 1002-1013.

Krogh EJ (1988) The garnet-clinopyroxene Fe-Mg geothermometer - A reinterpretation of existing experimental data, Contrib. Mineral. Petrol. 99: 44-48.

McDonough WF, Sun SS (1995) The composition of the Earth, Chem Geol 120: 223-253.

Norman MD, Garcia MO (1999) Primitive magmas and source characteristics of the Hawaiian plume: petrology and geochemistry of shield picrites, Earth Planet.Sci. Lett, 168: 27-44.

Polat A, Hofmann AW (2003) Alteration and geochemical patterns in the 3.7-3.8 Ga Isua greenstone belt, West Greenland, Precambrian Reseach 126: 197-218.

Schmickler B, Jacob DE, Foley SF (2004) Eclogite xenoliths fromthe Kuruman kimberlites, South Africa: geochemical fingerprinting of deep subduction and cumulate processes, Lithos 75(1-2): 173-207. 